\title{
La metáfora nupcial desde la mirada sinfónica de Hildegarda de Bingen*
}

Cecilia Avenatti de Palumbo*

Para citar este artículo: Avenatti de Palumbo, Cecilia. "La metáfora nupcial desde la mirada sinfónica de Hildegarda de Bingen". Franciscanum 161, Vol. LVI

(2014): 197-220.

\section{Resumen}

El artículo se propone interpretar Scivias y Symphonia, dos obras del corpus de Hildegarda de Bingen (teóloga, poeta, mística y visionaria del siglo xII cristiano, quien fue proclamada Doctora de la Iglesia por Benedicto XVI en octubre de 2012), a partir de la hermenéutica bíblica desarrollada por Paul Ricoeur en torno a la metáfora nupcial. El análisis de los textos logra demostrar que la música es el elemento distintivo de la nupcialidad hildegardiana y, por tanto, su aporte a la recepción del libro bíblico del Cantar de los Cantares.

\section{Palabras clave}

Hildegarda de Bingen, Cantar de los Cantares, metáfora nupcial, Paul Ricoeur.

Este estudio fue expuesto en el Coloquio: Hildegarda de Bingen, doctora para la Iglesia del siglo XxI, realizado por la Facultad de Filosofía y Letras y la Facultad de Teología de la Pontificia Universidad Católica Argentina, en Buenos Aires, el 23 de octubre de 2012.

Doctora en Letras por la Pontificia Universidad Católica Argentina, donde actualmente se desempeña como Profesora Titular Ordinaria de Estética en las facultades de Filosofía y Letras, Teología y Ciencias Sociales, Políticas y de la Comunicación. Ha publicado libros y artículos, participado en reuniones científicas en su país y en el extranjero. Sus investigaciones giran en torno al diálogo entre Literatura, Estética y Teología. Se ha especializado en Hans Urs von Balthasar y actualmente lleva adelante proyectos de investigación sobre la poesía mística y sobre Paul Ricoeur. Es directora de las Jornadas Diálogos entre Literatura, Estética y Teología, y fundadora de Alalite (Asociación Latinoamericana de Literatura y Teología) y de la Sección Literatura, Artes y Hermenéutica Bíblica. Recientemente ha sido designada como vicepresidente de la Sociedad Argentina de Teología por período 2013-2016. 


\title{
The bridal metaphor from the look of Hildegarda of Bingen
}

\begin{abstract}
The article intends to interpret Scivias and Symphonia, two works of the corpus of Hildegard von Bingen (theology, mystical and visionary poet of the 12 th century Christian, who was proclaimed a doctor of the Church by Benedicto XVI in October 2012), from the biblical hermeneutics developed by Paul Ricoeur around the bridal metaphor. The analysis of the texts manages to demonstrate that music is the distinctive element of the hildegardian thought and therefore her contribution to the reception of the biblical Book of the Song of Songs.
\end{abstract}

\section{Keywords}

Hildegard of Bingen, Song of songs, bridal metaphor, Paul Ricoeur.

La figura de Hildegarda de Bingen no solo se destaca como santa y doctora en teología, como música, poeta y científica, sino que también ocupa un lugar relevante en la historia de la lectura y recepción creativa del libro bíblico del Cantar de los cantares ${ }^{1}$. Heredera de la tradición alegórica y tipológica patrística iniciada por Orígenes ${ }^{2}$ y contemporánea de los comentarios de los cistercienses Bernardo de

1 Para una visión panorámica de la historia de la interpretación del Cantar, cf. Pablo R. Andiñach, Cantar de los cantares. El fuego y la ternura (Buenos Aires: Lumen, 1997), 31-36; Víctor Morla, Poemas de amor y de deseo. Cantar de los Cantares (Estella-Navarra: Verbo Divino, 2004), 58-81. Para una historia desde la perspectiva hermenéutica de la recepción lectora, cf. Paul Ricoeur, «La metáfora nupcial», en ed. André LaCocque y Paul Ricoeur, Pensar la Biblia. Estudios exegéticos y hermenéuticos (Barcelona: Herder, 2001), 285-303.

2 Cf. Orígenes, Comentario al Cantar de los Cantares (Madrid: Ciudad Nueva, 1994), 62 y 79-80 (Prólogo 3,15-16 y 1,1,1-5); Manlio Simonetti, «Introducción», en Orígenes, op. cit., 26-27; Samuel Fernández Eyzaguirre, «Introducción», en Orígenes, Homilías sobre el Cantar de los Cantares (Madrid: Ciudad Nueva, 2000), 15-19. 
Claraval y Guillermo de Saint-Thierry ${ }^{3}$, por su origen visionario, su interpretación teológica y su recreación plástica y poética del Cantar representan un aporte de singular valor. Para demostrarlo, seguiremos metodológicamente la huella trazada por Paul Ricoeur, quien al considerar el Cantar desde la perspectiva de la «metáfora nupcial» como camino hermenéutico de superación de la antinomia entre la lectura alegórica y la naturalista-erótica ${ }^{4}$, estableció la innovación semántica como posibilidad de ampliar la comprensión del texto bíblico y de sus recreaciones desde el horizonte del lector.

Nuestra primera hipótesis es que las visiones de Scivias y los cánticos poéticos de Symphonia ${ }^{5}$-que pertenecen a la primera etapa de su producción entre 1141 y $1161-^{6}$ pueden ser interpretados desde la «metáfora nupcial», de acuerdo con el sentido que Ricoeur confiere a la «metáfora viva»: un «ver como» en el que lo semejante es percibido en lo desemejante, sin sustitución de los términos, sino manteniendo la tensión e interacción de los mismos ${ }^{7}$. Si de este «ver como» se sigue la capacidad de innovación semántica y la referencialidad como lo propio de la vitalidad de la metáfora, cabe preguntarnos cuáles son los términos de la semejanza en la desemejanza que entran en juego en la nupcialidad hildegardiana. Sobre la base de esta primera cuestión, nuestra segunda hipótesis es que el elemento musical, que atraviesa la totalidad de su pensamiento teológico y de sus expresiones estéticas otorgándoles unidad y coherencia, constituye la nota distintiva y original de la «metáfora nupcial» hildegardiana que proponemos definir como sinfónica.

Cf. Jean Leclercq, El amor a las letras y el deseo de Dios. Introducción los autores monásticos de la Edad Media (Salamanca: Sígueme, 2009), 117-120; 243-294; Eva Reyes Gacitúa, El Espíritu Santo, origen de la esponsalidad. En la Expositio super Cantica canticorum de Guillermo de Saint-Thierry (Saarbrücken: Editorial Académica Española, 2012), 13-21; Marie-Madeleine Davy, Iniciación a la simbólica románica (Madrid: Akal, 1996) 68-73.

4 Paul Ricoeur, «La metáfora nupcial», op. cit., 275-311.

5 Se cita por las siguientes versiones: Hildegardis Bingensis, «Scivias», en ed. J.-P. Migne, Patrologiae cursus completus. Series Latina, 197 (Paris: Apud Garnier fratres, 1882); Hildegarda de Bingen, Scivias: Conoce los caminos (Madrid: Trotta, 1999); Hildegardis Bingensis, «Simphonia Armonie Celestium Revelationum», en Peter Dronke et alia, Hildegardis Bingensis Opera Minora (Turnhout: Brepols 2007); Hildegard de Bingen, Sinfonía de la armonía de las revelaciones celestiales (Madrid: Trotta, 2003). Cf. cronología en Azucena A. Fraboschi, Hildegarda de Bingen. La extraordinaria vida de una mujer extraordinaria (Buenos Aires: Ediciones de la Universidad Católica Argentina, 2004), 13-18. Cf. Paul Ricoeur, La metáfora viva (Madrid: Cristiandad, 1980), 237-291. 
Primero mostraremos las marcas nupciales en el texto hildegardiano a partir de la identificación de las figuras femeninas de Sapientia y Caritas con Ecclesia como la Esposa alegórica del Cantar. Luego presentaremos la symphonia o armonía musical como la innovación de sentido que inaugura la lectura hildegardiana de la metáfora nupcial. Finalmente, proyectaremos esta perspectiva sobre los lenguajes de la «nueva evangelización» a partir de la cual ha propuesto considerar su doctorado el papa Benedicto XVI ${ }^{8}$.

\section{Sapientia y Caritas como figuras esponsales: otra lectura alegórica del Cantar}

\subsection{Experiencia visionaria y lenguaje simbólico en el contexto cultural del siglo XII}

Las visiones de Hildegarda fueron interpretadas y expresadas en el contexto del lenguaje teológico y estético de su tiempo. Místicos y visionarios de todos los tiempos coinciden en recurrir al lenguaje de su ámbito cultural y religioso para expresar su experiencia de la acción de Dios, la cual sea objetiva o subjetiva es siempre personal y contextuada ${ }^{9}$. Hildegarda no fue la excepción a esta regla de oro fenomenológica en torno a la cual se articula la relación entre experiencia y lenguaje: ni experiencia pura sin lenguaje, ni pura construcción lingüístico-cultural sin experiencia, sino experiencia «y» lenguaje, porque como dice Ricoeur «toda experiencia es una síntesis de presencia e interpretación ${ }^{10}$.

8 «Y así el título de Doctora de la Iglesia Universal otorgado a Hildegarda de Bingen tiene un gran peso para nuestro tiempo y para las mujeres. (...) Por su capacidad de hablar con quienes están alejados de la fe y de la Iglesia, Hildegarda es un testigo creíble de la nueva evangelización». Benedicto XVI, «Carta Apostólica por la que Santa Hildegarda de Bingen, Monja Profesa de la Orden de San Benito, es proclamada Doctora de la Iglesia universal», L' Osservatore Romano 7 (8-9 octubre de 2012). Cf. Alois Maria Haass, «Mística en contexto», en ed. Victoria Cirlot y Amador Vega, Mística y creación en el siglo xx. Tradición e innovación en la cultura europea (Barcelona: Herder, 2006), 63-85; Juan Martín Velasco, El fenómeno místico (Madrid: Trotta, 2003), 36-64.

10 Citado por Juan Martín Velasco, op. cit., 43. Al estudio de esta temática he dedicado un artículo publicado recientemente: cf. Cecilia Inés Avenatti de Palumbo, «ટ̇Visionaria o mística? Hildegarda de Bingen en la encrucijada de lenguaje y experiencia del misterio cristiano», Teología 108, Vol. XLIX (2012): 11-24. 
Inserta en el contexto lingüístico de la teología monástica del siglo XII, que estaba centrada en la experiencia del deseo de Dios ${ }^{11}$, Hildegarda expresará su visión del misterio de Dios en el lenguaje simbólico de raíces bíblicas y lo interpretará en los términos de la exégesis alegórica de la patrística desarrollada a partir de los Comentarios al Cantar de Orígenes. En sintonía con esta forma sapiencial, Benedicto XVI señala que «las visiones místicas de Hildegarda son ricas en contenidos teológicos, hacen referencia a los principales acontecimientos de la historia de la salvación, y usan un lenguaje principalmente poético y simbólico»» ${ }^{12}$.

Al igual que el resto de sus contemporáneos, la abadesa de Bingen frecuentó el Cantar, que según Leclercq fue «el libro más leído y comentado en los claustros medievales» ${ }^{13}$, y asumió la interpretación de Orígenes quien, sobre la base alegórica ya realizada por la exégesis hebrea que había interpretado a los amantes del Cantar como Yahvé e Israel, sustituyó el sentido literal por el sentido espiritual provocando la consecuente abolición del erotismo, los cuales fueron alegorizados, tipológicamente, como el Esposo y la Esposa en el par Cristo e Iglesia, y, psicológicamente, en el par Cristo y el alma eclesiástica. Así lo entendió su primer biógrafo Theoderich von Echternach, cuando subrayó «que se le podrían aplicar [a Hildegarda] los versos del Cantar de los cantares: "Mi amado metió la mano por la hendedura; y por él se estremecieron mis entrañas" (Cant. 5,4)»14.

\subsection{Alegorías femeninas del Cantar: Ecclesia, Sapientia y Caritas}

Hildegarda asumió el lenguaje de la interpretación alegórica tradicional para expresar sus plásticas visiones, pero introdujo la innovación de concebir la esponsalidad eclesial bajo las figuras femeninas de Sapientia y Caritas que describió como virtudes o energías divinas.

11 Cf. Jean Leclercq, op. cit., 243-294

12 Benedicto XVI, «Santa Hildegarda de Bingen (II)», en Figuras femeninas del medioevo (Buenos Aires: Agape Libros, 2011) 11.

13 Jean Leclercq, op. cit., 117.

14 Victoria Cirlot (ed.), Vida y visiones de Hildegard von Bingen (Barcelona: Siruela, 2009), 49-50. 
Alegóricamente interpretada, Ecclesia es la predestinada Esposa de Cristo y así la representa en la parte central de Scivias (II, 6 Sacrificio de Cristo y la Iglesia), pero por ser su actividad principal sapiencial y creadora, Hildegarda concibe a Sapientia y Caritas también como figuras esponsales que identifica recíprocamente ${ }^{15}$, acercándose de este modo a la recuperación de la dimensión erótica que la espiritualización alegórica había excluido. Por ello, Barbara Newman, no duda en afirmar que «en el corazón de su universo espiritual, Hildegarda coloca la numinosa figura que llama Sapientia o Caritas, una forma visionaria que trasciende la alegoría y alcanza la estatura de una teofanía» ${ }^{16}$.

La integración armónica se presenta de modo paulatino. Mientras en la tercera parte de Scivias (III, v. 3, 8, 9) las figuras Sapientia y Caritas aparecen distinguidas una de la otra, en Simphonia el elemento musical las armoniza hasta identificarlas. El Amor aparece como la primera de las cinco imágenes de La torre de la premonición (Scivias III, v. 3) y entre las virtudes de La columna de la Salvación (Scivias III, v. 8). Sabiduría forma parte de La columna de la palabra de Dios (Scivias III, v. 4, 15) y de La torre de la Iglesia (Scivias III, v. 9). En cambio en la forma poéticomusical de Simphonia ambas figuras se unifican. Así, en la antífona 4, Sabiduría aparece en su plenitud como manifestación divina creadora que abraza al mundo con Amor. Que del Amor proviene el poder de la Sabiduría queda así expresado en el poema «O virtus sapientiae!» [iPotencia de la sabiduría!]:

15 Cf. Barbara Newman, Sister of Wisdom. St. Hildegard's Theology of the Feminine (Berkeley- Los Angeles: University of California Press, 1997), 48-49. 


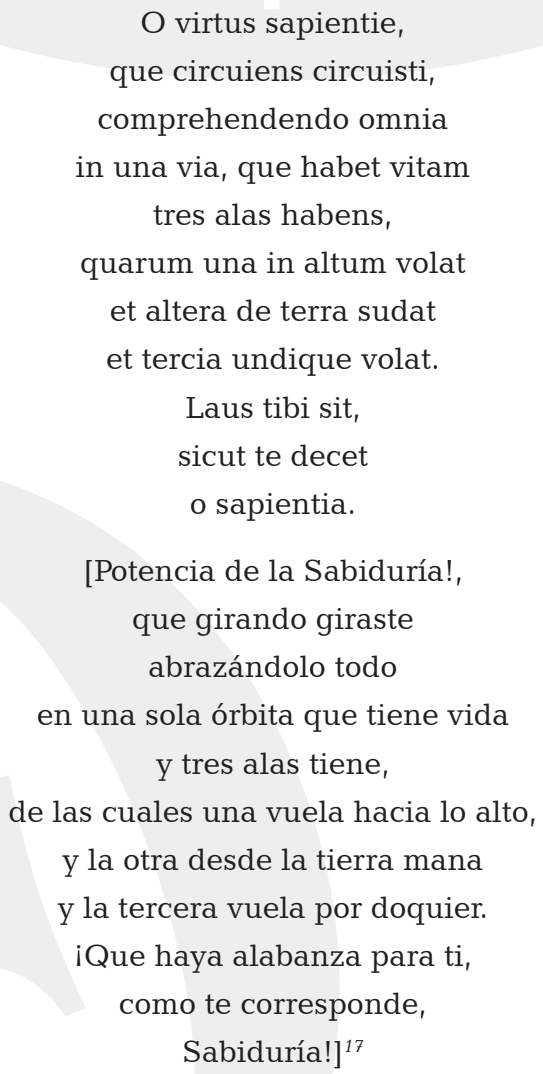

[Potencia de la Sabiduría!, que girando giraste abrazándolo todo en una sola órbita que tiene vida y tres alas tiene, de las cuales una vuela hacia lo alto, y la otra desde la tierra mana y la tercera vuela por doquier. iQue haya alabanza para ti, como te corresponde, Sabiduría! $]^{17}$

Sapientia se presenta aquí como dinamismo incesante del amor creador en las tres dimensiones del deseo de Dios, de la viriditas como fertilidad que proviene de Dios y que de allí se expande por la tierra y el amor que abraza y envuelve, consumando el acuerdo armónico entre el microcosmos y el macrocosmos. Similar identificación consonante entre Sapientia y Caritas se advierte en la antífona novena llamada «Karitas habundat» [La caridad abunda]:

17 «O virtus sapientiae» [iPotencia de la sabiduría!], en Hildegard de Bingen, Sinfonía de la armonía de las revelaciones celestiales, op. cit., 51. 


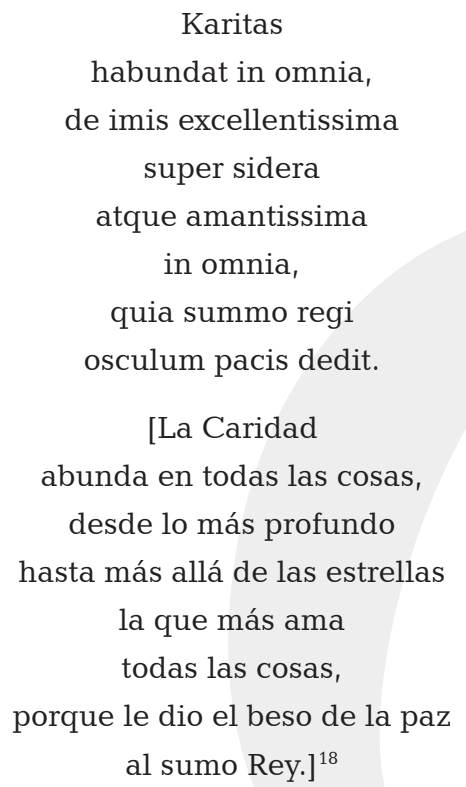

Fuerza vital y espiritual, Caritas, que unida a Sapientia todo lo abarca, es la Esposa de Dios que en el Libro de los merecimientos de la vida (III, 8), en clara alusión al Cantar bíblico, exclama: «Yo soy la esposa amante en el trono de Dios, y Él no esconde nada de mí. Yo mantengo el lecho real y todo lo que le pertenece a Dios me pertenece también a mí» ${ }^{19}$. El beso de la unión amorosa, que desea la amante del Cantar, es la causa del amor excesivo que se derrama inagotable sobre el mundo y el hombre, anunciando lo que el elemento musical confirmará como el fundamento más profundo de la relación entre Dios y su creación: que en el principio era la acción del amor, no solo en el origen mítico del mundo, sino en la cotidianidad de la presencia divina en la vida histórica del hombre. La unión no es fin sino comienzo, no es meta que deba ser alcanzada con esfuerzo desde el hombre, sino don entregado en abundancia. A pesar del carácter innovador de las figuras esponsales de Amor y Sabiduría, la superación de la alegorización se consuma en virtud de la incorporación de la música como segundo 
elemento de innovación hildegardiana. Siguiendo a Newman y Dronke, Flisfisch destaca que Hildegarda «fue la primera autora mística que personificó a Caritas como hermosa figura femenina» ${ }^{20}$. También es femenina Sapientia, el «alter ego» de Caritas, en quien se consuman «las nupcias eternas del Esposo con la humanidad». Por ello, ellas se encuentran unidas a Ecclesia, figura concebida como «la epifanía final de lo femenino e, históricamente, la última manifestación del secreto eterno ${ }^{21}$. Será por este motivo que Balthasar al referirse a la escucha como disposición del teólogo, haya señalado que «frente a la revelación no se da una objetividad científica neutral y desinteresada. Solo se da el diálogo personal de Palabra y fe, Cristo e Iglesia en el misterio del Cantar de los cantares. Si la Iglesia entiende es santa; y en la medida que es santa entiende $»^{22}$.

Dos fragmentos poéticos evidencian la esponsalidad que une a estas dos figuras en la tercera. Entre los Himnos a la Iglesia, se destaca la antífona 47 cuando dice «Que se regocijen ahora las entrañas maternas / de la Iglesia, / porque en suprema sinfonía / sus hijos / se han establecido en su regazo ${ }^{23}$. La unidad se manifiesta como sinfonía, manifestación teofánica del amor concebido en la figura del regazo materno que es la misma que en Scivias representa Cuerpo místico (II, v. 5). La figura musical que rige el dinamismo de esta antífona se entrecruza con la figura esponsal de la antífona 49 que dice: «iFulgurante luz de las estrellas, / deslumbrante figura elegida / para las nupcias reales, / brillante gema! $»^{24}$. De este modo, la música que unifica a estas tres figuras femeninas esponsales nos lleva hasta el umbral del segundo planteo de nuestro trabajo, a saber,

20 María Isabel Flisfisch, «Las figuras femeninas en la Symphonia de Hildegard de Bingen: Caritas, Sapientia y Ecclesia», Revista Chilena de Literatura 62, (2003): 129.

21 Íbid., 135.

22 Hans Urs von Balthasar, «Teología y santidad», en Ensayos teológicos I Verbum Caro (Madrid: Cristiandad, 1964), 261.

23 «Nunc gaudeant» [«Que se regocijen ahora»], en Hildegard de Bingen, Sinfonía de la armonía de las revelaciones celestiales, op. cit., 253-254.

24 «O choruscans lux stellarum» [«Fulgurante luz de las estrellas»], Ibíd., 262. 
el papel de la symphonia en la recreación hildegardiana del Cantar de los cantares desde la hermenéutica de metáfora nupcial.

\section{La symphonia como innovación semántica de la metáfora nupcial hildegardiana}

No obstante su pertenencia a esta tradición patrística y monástica de la mística nupcial, la incorporación de la música como eje de la configuración de su pensamiento otorga tal originalidad a su obra que hace que la nupcialidad subsista más allá de la caída de su significado espiritual, que se sostenía en el vínculo entre tradición alegórica y condición monástica, tradición hoy transfigurada en virtud de la valoración cristiana de la sexualidad. En esta parte, primero, situaremos el papel de la música en la cosmovisión de Hildegarda; segundo, nos referiremos al sentido ricoeuriano de metáfora nupcial, que metodológicamente nos ha permitido la incorporación de la música junto al amor en el mismo campo semántico de referencia; y, tercero, definiremos cuál es la nupcialidad que la música revela a partir de la innovación semántica de la metáfora hildegardiana.

\subsection{El papel de la música en la cosmovisión de Hildegarda}

De la tradición pitagórica medieval, que se difundió a través de la obra De institutione musica de Boecio, Hildegarda hereda la concepción que distingue entre música mundana o de las esferas, música humana, en la que se integran alma y cuerpo y la música instrumental o artificial. Sin embargo, mientras la escuela pitagórica se interesaba por la música especulativa en desmedro de la corporalidad del canto, Hildegarda tenía el canto en alta estima, al punto que consideraba el sonido como principio divino, razón por la cual hay quienes se inclinan por ubicarla en la tradición musical neoplatónica ${ }^{25}$.

25 La hipotética relación se habría dado entre Hildegarda y el teórico carolingio Regino de Prün, «quien asociaba la música humana de Boecio con el canto y distinguió la música artificial de la natural valorando más esta segunda». María Isabel Flisfisch, «Introducción», en Hildegard de Bingen, Sinfonía de la armonía de las revelaciones celestiales, op. cit., 23. Cf. Barbara Newman, «Introduction», en Hildegard of Bingen, Simphonia (New York: Cornell University Press, 1998), 20. 
En este contexto, Barbara Newman señala que «la palabra symphonia era empleada en la Edad Media muy libremente y podía significar tanto melodía como armonía, o simplemente música en general, tanto vocal como instrumental $»^{26}$ y por ello propone traducir el título «Symphonia armonie celestium revelationum» como «Música armoniosa de los misterios celestiales» ${ }^{27}$. Esta obra está compuesta por poemas, en su mayoría litúrgicos, con anotación musical. Palabra y música participan del mismo carácter revelado de las visiones, a tal punto, que se ha propuesto considerarlas como «visiones auditivas» ${ }^{28}$.

Según Fuentes ${ }^{29}$, para Hildegarda, el sonido emerge como el primer gesto de la creación antes que la luz, por eso la música está en el principio y permanece en el cosmos, en el alma humana y en los instrumentos, en la tensión dramática que existe entre su condición de creación original, la caída con su consecuente pérdida de la armonía y el camino hacia la reintegración de la unidad por la música. Este drama musical se da en una dirección descendente -la música en tanto revelada viene desde lo alto y resuena en el hombre y en el mundo- y ascendente-la música en tanto recordada cobra forma en la voz humana y en los instrumentos-. La síntesis de ambas direcciones es Cristo, ya que él encarna la "prima vox» descendente y a la vez se hace eco del lamento de la creación. Así, en la antífona 6, le canta al «iPastor de almas / y voz primera, / por la que todos fuimos creados!» ${ }^{30}$ y en la antífona 7, cuando dice: «iSangre derramada, / que en lo alto resonaste, / cuando todos los elementos / se confundieron / con un temblor / en una voz de lamento, / porque la sangre de su Creador los tocó!» ${ }^{31}$.

\footnotetext{
26 Ibíd., 11.

27 Ibíd., 12

28 Ítalo Fuentes Bardelli y María José Ortúzar Escudero, «Música e Historia en Hildegard von Bingen», Revista Chilena de Literatura 62 (2003), 148.

29 Cf. Ítalo Fuentes Bardelli, «La música en la Symphonia de Hildegard von Bingen», en Coloquio Mujeres de la Edad Media: escritura, visión, ciencia: a novecientos años del nacimiento de Hildegard von Bingen (Santiago de Chile: Universidad de Chile, 1998) 79-89.

30 "O pastor animarum / et o prima vox, / per quam omnes creati sumus, / [...]», «O pastor animarum» [iOh pastor de las almas!], en Hildegard de Bingen, Sinfonía de la armonía de las revelaciones celestiales, op. cit., 58.

31 «O cruor sanguinis / qui in alto sonuisti, / cum ominia elementa / se implicuerunt/ in lamentabilem vocem / cum tremore, / quia sanguis creatoris sui illa tetigit: /», «O cruor sanguinis» [iSangre derramada!], en Hildegard de Bingen, Sinfonía de la armonía de las revelaciones celestiales, op. cit., 61.
} 
Puente entre lo material y lo inmaterial, entre la eternidad y la historia, en el eje melodía y palabra se gesta la unión propia de la forma simbólica ${ }^{32}$. La resonancia en el mundo de la "primera voz» es llevada a cabo por los coros angélicos, que son las «voces más prístinas que ayudan en la tarea divina de hacer fluir las armonías fecundantes, produciendo consonancias en el universo, el alma humana y la naturaleza» ${ }^{33}$. Uno de los textos fundamentales para la teoría de la música hildegardiana es la «Carta a los prelados de Maguncia» que escribe un año antes de su muerte entre 1178 y 1179 , en defensa ante la injusta prohibición del canto litúrgico a la que había sido sometida la comunidad benedictina a su cargo ${ }^{34}$. Señala allí el «acuerdo» entre lo exterior y lo interior que produce la música, el «origen divino» descendente de la armonía, ante la cual el canto humano es respuesta, la «afinidad» originaria entre el canto angélico con el humano y la posibilidad de recuperarlo por la revelación descendente y la memoria ascendente de la voz. El hombre tiene «vocación sinfónica», pues «en la voz de Adán residía el sonido de toda armonía y la dulzura de todo arte musical», que recupera cada vez que canta y que «pierde cada vez que las discordias, escándalos o injustas represiones» lo alejan de la armonía primera.

Teológicamente, el cuerpo de Cristo es a María por medio del Espíritu Santo, como la música armoniosa es a Ecclesia por medio de la acción del Espíritu que los inspira. La dignidad corporal de la música queda sintetizada por Hildegarda en la imagen que indica que «el cuerpo es el vestido del alma, que tiene una voz viva, y por eso conviene que el cuerpo unido al alma cante sus alabanzas a Dios con esa voz» ${ }^{35}$.

32 Ítalo Fuentes Bardelli y María José Ortúzar Escudero, op. cit., 148.

33 Ibíd., 149.

34 Para la cuestión de las fuentes y el contexto de esta Carta n. ${ }^{\circ} 23$, cf. Delia Buisel De Sequeiros, «La carta de Hildegarda de Bingen al capítulo de Maguncia y el origen del canto litúrgico de las Horas», en ed. Azucena A. Fraboschi, Desde el fulgor de la Luz Viviente... Hildegarda, abadesa de Bingen (Buenos Aires: Educa, 2007), 85-96.

35 Las referencias a la Carta 23 de Hildegarda está tomada de la traducción inédita de Azucena Fraboschi. Hildegardis Bingensis Epistolarium (Turnhout: Brepols, 1991-93), 91. 
Así «el alma es sinfónica» porque puede responder cantando e interpretando instrumentos en la materialidad de su cuerpo y por todo ello está llamado el hombre a configurar el décimo coro angélico ${ }^{36}$. Si bien, señala Clara Cortázar, este concepto no es de Hildegarda sino que «ella lo heredó de Pitágoras, de Platón en el Timeo, de Boecio y de San Agustín ${ }^{37}$, sin embargo, el acento en la corporeidad de la música y el origen visionario del dinamismo descendente y ascendente son propios de la abadesa de Bingen. La sinfonía conduce hacia lo divino a partir de la materia y lo eterno originario se actualiza en el tiempo histórico, en virtud del carácter de duración la música, con lo cual se logra una concordancia entre historia, música y creación divina ${ }^{38}$. Es el misterio de la Encarnación del Verbo presentificado en la encarnación del sonido en la voz y los instrumentos humanos, por medio de lo cual se produce el encuentro con Dios y con los hombres que cantan reunidos. Como concluyen Fuentes y Ortúzar, «la música no solo está integrada en el ritmo y melodía de los poemas, cosa que de suyo sería suficiente, sino forma parte substancial del contenido de sus visiones y de la arquitectura de su cosmos» ${ }^{39}$.

En su circularidad histórica (creación, caída y reintegración), la música es anterior a la historia en tanto es «vox prima» presente en la palabra creadora, y la supera al final pues pertenece a lo eterno en tanto se proyecta en el cosmos celestial como sinfonía ${ }^{40}$. «Tal vez la música -arriesgan Fuentes y Ortúzar- antes que la alegoría desarrollada en sus obras visionarias, era la traducción más fiel de lo que le presentaba Dios a su oído, del mensaje divino que ella escuchaba ${ }^{41}$. A partir de esta insinuación nosotros proponemos ahora mostrar que en Symphonia, la música supera a la alegoría, en razón de que la música es una metaforización del amor.

\footnotetext{
36 Ibíd., 61-66.

37 Cf. Clara Cortazar, «Hildegarda de Bingen compositora: nova et vetera», en ed. Azucena A. Fraboschi, Desde el fulgor de la Luz Viviente... Hildegarda, abadesa de Bingen, op. cit., 97-122.

38 Cf. Ítalo Fuentes Bardelli y María José Ortúzar Escudero, Ibíd., 155.

39 Ibíd., 153.

40 Cf. Ibíd., 156

41 Ibíd., 158.
} 


\subsection{La metáfora nupcial de Paul Ricoeur en la symphonia hildegardiana}

La propuesta hermenéutica de Paul Ricoeur sobre la «metáfora viva» nos guiará en la etapa conclusiva de nuestra reflexión. Señalaremos aquí solo algunos puntos sobresalientes en vistas a su aplicación al texto hildegardiano. En primer lugar, destaca el autor el efecto de torsión o impertinencia semántica que se opera en virtud de la reunión de campos semánticos heterogéneos, los cuales no se anulan sino que se mantienen en tensión en virtud de una interpretación cuya referencialidad es el mundo del texto ${ }^{42}$. En segundo lugar, también subraya que la metáfora poética suspende la función descriptiva para liberar una función referencial más originaria. Esta función referencial del discurso poético es cercana a la de la revelación en tanto desoculta un arraigo originario que había permanecido oculto ${ }^{43}$.

Cuando aplica este proceso a la hermenéutica del Cantar de los cantares $^{44}$, Ricoeur afirma que, a diferencia del mito genesíaco que narra el comienzo de inocencia del amor, este poema bíblico canta el renacimiento continuo de la inocencia del amor en el corazón mismo de la existencia cotidiana. Metafóricamente, lo que el lenguaje poético libera es la comprensión del vínculo nupcial como amor libre y fiel, que ni exige ni excluye lo conyugal. Ricoeur observa que la liberación del sentido nupcial -vínculo que expresa la fidelidad y libertad del amor- se produce en las marcas de lo erótico que estructuran el texto bíblico, marcas que constituyen el sentido literal, el cual, por efecto de la metaforización, queda suspendido para dar lugar a la referencia segunda, que es donde se produce la innovación de sentido. A tal punto la nupcialidad se expresa en el lenguaje erótico que, para Ricoeur, si

Tres supuestos teóricos de la metáfora viva a tener en cuenta al momento de comprender y aplicar la propuesta ricoeuriana de interpretar el Cantar de los Cantares desde la metáfora nupcial son: la referencialidad, la semejanza y la innovación de sentido, tema que hemos abordado recientemente: cf. Cecilia Inés Avenatti de Palumbo, «La metáfora nupcial como provocación a la literatura y a la teología», Teolitéraria 4, Vol. 2 (2012): consultada en noviembre 13, 2013. www.teoliteraria.com/tlj/ index.php/tlt/article/view/63.

43 Cf. Paul Ricoeur, «Nombrar a Dios», en Fe y Filosofía. Problemas del Lenguaje Religioso (Buenos Aires: Almagesto-Docencia, 1990), 105-106.

44 Cf. Paul Ricoeur, «La metáfora nupcial», op. cit., 275-311. 
este fuera sustituido por el sentido espiritual, la experiencia mística enmudecería pues carecería de medios para expresarse. Lo erótico no es una ilusión sino una figura de la totalidad del amor que, junto con la figura espiritual, refieren a la nupcialidad como vínculo.

Desde el punto de vista literario, la crítica coincide en considerar el Cantar como un texto ni narrativo ni dramático, sino lírico. De acuerdo con esto, al interpretar la estructura literaria del texto la atención no ha de ponerse ni en la trama ni los personajes ni en la historia, sino en el canto. Más allá de las etapas recorridas hasta la fijación definitiva del texto, lo cierto es que desde su aceptación canónica en el siglo iı gracias a la intervención del Rabí Aqiba ${ }^{45}$, este libro bíblico fue titulado por una

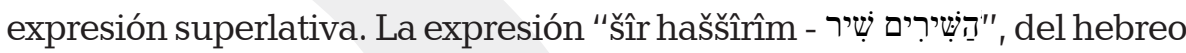

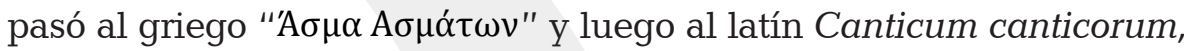
refiriendo en todos los casos a la condición musical del poema en su máxima potencialidad, razón por la cual podría traducirse como «el mejor de los cantares», «el cantar por excelencia», «el más sublime de los cantares $»^{46}$. Ricoeur advierte en su análisis la importancia de la música en el proceso de metaforización cuando al referirse al sentido de los movimientos del Amor en el espacio del poema, señala que la consumación del amor entre los amantes (por ejemplo en Cant 5,1 o $6,3)$ no es descripta sino cantada. Desde la perspectiva de la teoría hildegardiana de la música podríamos preguntarnos si no será acaso porque el canto mismo es la consumación del amor ${ }^{47}$.

Al aplicar el proceso metafórico ricoeuriano a la obra de Hildegarda, la fuerza de gravedad de la symphonia, que en su cosmovisión todo lo atraviesa y abraza, provoca una expansión del campo semántico de la nupcialidad hacia un nuevo sentido que se opera en virtud de la música. Así como para Ricoeur la metáfora nupcial estructuraba la totalidad del texto bíblico del Cantar, así también Hildegarda, sobre la base de la centralidad cósmica y escatológica de su «teología

Cf. Víctor Morla, op. cit., 23-25.

Cf. Ibíd., 20-21.

Paul Ricoeur, «La metáfora nupcial», op. cit., 281. 
de la música ${ }^{48}$, encuentra en la armonía sinfónica la clave para la configuración de su obra. Dicho en lenguaje hermenéutico, el mundo del texto hildegardiano en el que se manifiesta la verdad es la música. Quizás en vista de esta riqueza intuida, la Carta apostólica de su proclamación como Doctora de la Iglesia universal, señale en uno de sus párrafos que «el lenguaje de Hildegarda, caracterizado por un estilo nuevo y eficaz, recurre espontáneamente a expresiones poéticas que se distinguen por su claro simbolismo, a lo que se añaden sus fulgurantes intuiciones, las analogías concisas y las sugestivas metáforas» ${ }^{49}$.

\subsection{La nupcialidad que la música revela:}

la innovación semántica de la metáfora

En la parte final de nuestra exposición mostraremos los indicios de lo nupcial-musical en los últimos poemas de Symphonia. El canto 66, titulado «O dulcissime amator», al igual que el siguiente, son los únicos poemas que aparecen acompañados por la forma «symphonia», la cual a diferencia de los otros tipos poético-musicales (como las antífonas, responsorios, himnos y secuencias) no tiene sentido litúrgico, lo que ha sido interpretado como una referencia explícita a la sinfonía como «melodía preexistente, no una creación, sino una visión», "eco del paraíso o sonido anterior al eco de los ángeles o de las armonías celestiales ${ }^{50}$. Citamos algunas de las estrofas más explícitamente referidas al imaginario nupcial del Cantar:

$$
\begin{gathered}
\text { O Dulcissime amator, } \\
\text { o dulcissime amplexator: } \\
\text { adiuva nos custodire } \\
\text { virginitatem nostram. }
\end{gathered}
$$$$
[\ldots]
$$

48 Cf. Christine V. Paintner, «La estética como vinculación entre la práctica espiritual y el cultivo de la virtud en la teología de la música de Hildegardis de Bingen», Cuadernos Monásticos 151 (2004): 485-505.

49 Benedicto XVI, «Carta Apostólica por la que Santa Hildegarda de Bingen, Monja Profesa de la Orden de San Benito, es proclamada Doctora de la Iglesia universal», op. cit., n. ${ }^{\circ} 3$.

50 Hildegard de Bingen, Sinfonía de la armonía de las revelaciones celestiales, op. cit., 376. 
5. Nunc te advocamus te sponsum et consolatorem, qui nos redimisti in cruce.

6. In tuo sanguine copulaste sumus tibi cum desponsatione repudiantes virum et eligentes te, filium dei.

7. O pulcherrima forma, o suavissime odor desiderabilium deliciarum, semper suspiramus post te in lacrimabili exilio.

Quando te videamus et tecum maneamus?

8. Nos sumus in mundo, et tu in mente nostra, et amplectimur te in corde, quasi habeamus te presentem.

$$
\text { [...] }
$$

10. Da nobis societatem cum illa Et permanere in te, o dulcissime sponse,

$$
\text { [...]. }
$$

[1.iTú, el más dulce amante,

el de los más dulces abrazos!, ayúdanos a defender nuestra virginidad.

$$
\text { [...] }
$$


5. Ahora te invocamos

Esposo y Consolador, que nos redimiste en la cruz.

6. En tu sangre

nos hemos unido a ti en esponsales

renunciando a un varón

y eligiéndote a ti,

Hijo de Dios.

7. i[Tú], la más hermosa forma!

i[Tú], la más dulce fragancia de deseables delicias!

¿Cuándo podremos verte

y permanecer contigo?

8. Estamos en el mundo,

y tú en nuestra mente,

y te abrazamos con el corazón

como si estuvieras presente.

$$
\text { [...] }
$$

10. Danos alianza con ella

y concédenos permanecer en ti, dulcísimo esposo. $]^{51}$

Tras las huellas de Newman, coincide la crítica en afirmar la relación de este poema con la piedad nupcial tradicional procedente de la lectura origenista y del «medio emocional de los sermones de San Bernardo acerca del Cantar» ${ }^{52}$. Sin embargo, las marcas en el texto poético tales como «dulce amante», «dulces abrazos», «Esposo

51 «O dulcissime amator. Symphonia virginum» [iTú, el más dulce amante...! Sinfonía de las vírgenes], Ibíd., 373-376.

52 Cf. Ibíd., 377 y 379. 
y consolador», «unido en esponsales», «hermosa forma», «dulce fragancia», «deseable delicia», son imágenes nupciales que adquieren valor metafórico cuando son interpretadas en la intersección con las metáforas sinfónicas. Estas marcas musicales las encontramos en otros poemas que constituyen la serie de Cantos misceláneos con que se clausura la obra poética Symphonia, donde se alaba al Dios Trino como «música y vida» ${ }^{53}$, y donde María dice en referencia a la Encarnación: «[Dios] ha plantado en mis entrañas / toda clase de música ${ }^{54}$. Los dos campos semánticos heterogéneos que se reúnen en la metáfora nupcial hildegardiana son el amor y la música. Si la música es para Hildegarda revelación de la armonía celeste y la symphonia es melodía preexistente, entonces, lo que la música revela es que la nupcialidad como vínculo se encuentra en el origen de todo amor que, por ser tal, es libre y fiel. Según esto podríamos afirmar que para Hildegarda el Esposo es «amante dulcísimo» porque es música. Y, por lo tanto, a la pregunta por el contenido de los poemas de Hildegarda, podríamos responder que hablan del amor y de la música como armonía cósmica e histórica, de la symphonia como manifestación de la creación original, la caída y la reintegración, que son los caminos del vínculo nupcial en su libertad y fidelidad.

«Estas obras nacen de una íntima experiencia mística, y proponen una eficaz meditación acerca del misterio de Dios $»^{55}$, dice Benedicto XVI en la Carta Apostólica del doctorado. Los dos elementos propios de la mística están presentes en Hildegarda: por ello, piden las vírgenes se les conceda la experiencia de la unión cuando dicen «estamos en el mundo / y tú en nuestra mente», «te abrazamos con el corazón», «concédenos permanecer». Haber expresado en el lenguaje de la metáfora nupcial-musical el misterio de Dios es una novedad que aguardó novecientos años para ser comprendida como tal. Hoy

53 «Laus trinitati, / qui sonus et vita / ac creatrix ómnium / in vita ipsorum est, [...]», «Laus Trinitati» [Alabanza a la Trinidad], Ibíd., 387.

54 «[...] et in visceribus meis / omne genus musicorum, / in omnibus floribus tonorum constituit: // [...]». «O Fili dilectissime» [Amadísimo Hijo], Ibíd., 390-391.

55 Benedicto XVI, «Carta Apostólica por la que Santa Hildegarda de Bingen, Monja Profesa de la Orden de San Benito, es proclamada Doctora de la Iglesia universal», op. cit., n. 3. 
cuando los caminos de la mística y de la belleza son transitados como respuesta al desafío de la nueva evangelización, la nupcialidad y la música se presentan junto a la mística y la belleza también como lugares teológicos a explorar.

\section{Bibliografía}

Andiñach, Pablo R. Cantar de los cantares. El fuego y la ternura. Buenos Aires: Lumen, 1997.

Avenatti de Palumbo, Cecilia Inés. «¿Visionaria o mística? Hildegarda de Bingen en la encrucijada del lenguaje y experiencia del misterio cristiano». Teología 108, Vol. XLIX (2012): 11-24.

. «La metáfora nupcial como provocación a la literatura y a la teología». Teolitéraria 4, Vol. 2 (2012): consultada en noviembre 13, 2013. www.teoliteraria.com/tlj/index.php/tlt/ article/view/63

Balthasar, Hans Urs von. «Teología y santidad». En Ensayos teológicos I Verbum Caro, 235-268. Madrid: Cristiandad, 1964.

Benedicto XVI. «Santa Hildegarda de Bingen (I)». En Figuras femeninas del medioevo, 7-9. Buenos Aires: Agape Libros, 2011.

. «Santa Hildegarda de Bingen (II)». En Figuras femeninas del medioevo, 11-15. Buenos Aires: Agape Libros, 2011.

. «Homilía en la Santa Misa para la apertura del sínodo de los obispos y proclamación como Doctores de la Iglesia de San Juan de Ávila y de Santa Hildegarda de Bingen». Roma, Plaza de San Pedro, 7 de octubre de 2012.

- «Carta Apostólica por la que Santa Hildegarda de Bingen, Monja Profesa de la Orden de San Benito, es proclamada Doctora de la Iglesia universal». Vaticano: L'Osservatore Romano, 8-9 octubre 2012. 
Bingen, Hildegarda de. El libro de los merecimientos de la vida. Introducción, traducción y notas por Azucena A. Fraboschi. Buenos Aires: Miño y Dávila, 2011.

. Epistolarium. Turnhout: Brepols, 1991-93.

. Libro de las Obras Divinas. Traducido por María Isabel Flisfisch, María Eugenia Góngora y María José Ortúzar. Barcelona: Herder, 2009.

. «Scivias». En Patrologiae cursus completus. Series Latina, editado por J.-P. Migne, 197. Paris: Apud Garnier fratres, 1882.

. Scivias: Conoce los caminos. Traducción por Antonio Castro Zafra y Mónica Castro. Madrid: Trotta, 1999.

. Sinfonía de la armonía de las revelaciones celestiales. Traducido por María Isabel Flisfisch; introducción y comentarios por María Isabel Flisfisch, María Eugenia Góngora, Italo Fuentes, Beatriz Meli y María José Ortúzar. Madrid: Trotta, 2003.

. Symphonia. Introduction, translations, and commentary by Barbara Newman. New York: Cornell University Press, 1998.

. «Symphonia Armonie Celestium Revelationum». En Hildegardis Bingensis Opera Minora, editado por Peter Dronke y otros. Turnhout: Brepols, 2007.

. «Ordo virtutum». En Hildegardis Bingensis Opera Minora, editado por Peter Dronke y otros. Turnhout: Brepols, 2007.

Buisel de Sequeiros, Delia. «La carta de Hildegarda de Bingen al capítulo de Maguncia y el origen del canto litúrgico de las Horas». En Desde el fulgor de la Luz Viviente... Hildegarda, abadesa de Bingen, editado por Azucena A. Fraboschi, 8596. Buenos Aires: Educa, 2007. 
Cirlot, Victoria. Hildegard von Bingen y la tradición visionaria de Occidente. Barcelona: Herder, 2005.

. (ed.) Vida y visiones de Hildegard von Bingen. Barcelona: Siruela, 2009.

Cortazar, Clara. «Hildegarda de Bingen compositora: nova et vetera». En Desde el fulgor de la Luz Viviente... Hildegarda, abadesa de Bingen, editado por Azucena A. Fraboschi, 97-122. Buenos Aires: Educa, 2007.

Cymbalista, Cándida María. «Hildegarda». Cuadernos Monásticos 151 (2004): 469-484.

Davy, Marie-Madeleine. Iniciación a la simbólica románica. Madrid: Akal, 1996.

Fernández Eyzaguirre, Samuel, «Introducción». En Orígenes. Homilías sobre el Cantar de los Cantares, 5-40. Madrid: Biblioteca de Patrística, Ciudad Nueva, 2000.

Flisfisch, María Isabel. «Las figuras femeninas en la Symphonia de Hildegard de Bingen: Caritas, Sapientia y Ecclesia». Revista Chilena de Literatura 62 (2003): 127-144.

. «Introducción». En Hildegard de Bingen. Sinfonía de la armonía de las revelaciones celestiales, 15-31. Madrid: Trotta, 2003.

Fraboschi, Azucena. Bajo la mirada de Hildegarda, abadesa de Bingen. Buenos Aires: Miño y Dávila, 2010.

. Hildegarda de Bingen. La extraordinaria vida de una mujer extraordinaria. Buenos Aires: Educa, 2004.

Fraboschi, Azucena. Scivias de Hildegarda de Bingen. Lectura y comentario al modo de una lectio medievalis. Primera Parte. Buenos Aires: Miño y Dávila, 2009.

. Santa Hildegarda de Bingen. Doctora de la Iglesia. Buenos Aires: Miño y Dávila, 2012. 
Fuentes Bardelli, Ítalo. «La música en la Symphonia de Hildegard von Bingen». En Coloquio Mujeres de la Edad Media: escritura, visión, ciencia: a novecientos años del nacimiento de Hildegard von Bingen, 79-89. Santiago de Chile: Universidad de Chile, 1998.

Fuentes Bardelli, Ítalo y Ortúzar Escudero, María José. «Música e Historia en Hildegard von Bingen». Revista Chilena de Literatura 62 (2003): 145-163.

González de Cardedal, Olegario. Cristianismo y mística. Santa Teresa de Jesús - San Juan de la Cruz. Buenos Aires: Educa, 2013.

Haas, Alois Maria. «Mística en contexto». En Mística y creación en el siglo Xx. Tradición e innovación en la cultura europea, editado por Victoria Cirlot y Amador Vega, 63-85. Barcelona: Herder, 2006.

Leclercq, Jean. El amor a las letras y el deseo de Dios. Introducción los autores monásticos de la Edad Media. Salamanca: Sígueme, [1963] 2009.

Morla, Víctor. Poemas de amor y de deseo. Cantar de los Cantares. Estella (Navarra): Verbo Divino, 2004.

Newman, Barbara. Sister of Wisdom. St. Hildegard's Theology of the Feminine. Berkeley- Los Angeles: University of California Press, [ $\left.{ }^{1} 1987\right] 1997$. . «Introduction». en Hildegard of Bingen, Simphonia, 1-63. New York: Cornell University Press, [1988] 1998.

Orígenes. Comentario al Cantar de los Cantares. Introducción y notas de Manlio Simonetti, traducido por Argimiro Velasco Delgado. Madrid: Ciudad Nueva, [1986] 1994.

. Homilías sobre el Cantar de los Cantares. Introducción, traducción y notas por Samuel Fernández Eyzaguirre. Madrid: Ciudad Nueva, 2000. 
Ortiz, María Esther. "Algunos aspectos literarios en Symphonia, de Hildegarda de Bingen». En Desde el fulgor de la Luz Viviente... Hildegarda, abadesa de Bingen, editado por Azucena A. Fraboschi, 149-158. Buenos Aires: Educa, 2007.

Paintner, Christine V. «La estética como vinculación entre la práctica espiritual y el cultivo de la virtud en la teología de la música de Hildegardis de Bingen». Cuadernos Monásticos 151 (2004): 485-505.

Ricoeur, Paul. «La metáfora nupcial». En Pensar la Biblia. Estudios Exegéticos y Hermenéuticos, editado por André Lacoque y Paul Ricoeur, 275-311. Barcelona: Herder, 2001. . La metáfora viva. Madrid: Cristiandad, [1975] 1980. . «Nombrar a Dios». En Fe y Filosofía. Problemas del Lenguaje Religioso, 99-123. Buenos Aires: Almagesto-Docencia, 1990.

Reyes Gacitúa, Eva. El Espíritu Santo, origen de la esponsalidad. En la Expositio super Cantica canticorum de Guillermo de SaintThierry. Saarbrücken: Editorial Académica Española, 2012.

Simonetti, Manlio. «Introducción». En Orígenes. Comentario al Cantar de los Cantares, 7-31. Madrid: Ciudad Nueva, [1986] 1994.

Velasco, Juan Martín. El fenómeno místico. Madrid: Trotta, 2003. 